ROCZNIKI PEDAGOGICZNE

Tom 12(48), numer $1-2020$

DOI: http://dx.doi.org/10.18290/rped20121-10

PAWEŁ SKRZYDLEWSKI

\title{
FILOZOFIA WŁADZY \\ W UJĘCIU O. JACKA WORONIECKIEGO
}

\author{
Widzimy tedy, \\ że umiejętność rządzenia i rozkazywania \\ w szczególny sposób zasługuje u nas, \\ abyśmy się nad nią zastanowili: \\ jest to jedno z centralnych zagadnień pedagogiki polskiej \\ (Woroniecki, 1992, s. 12)
}

\section{WSTĘP}

Sługa Boży o. Jacek Woroniecki należy do grona najwybitniejszych Polaków XX wieku, osób, które niezwykle mocno wpłynęły na kształt i treść całej polskiej kultury, a wpływu tego nie sposób przecenić (Wistuba, 2003, s. 235-246). Jego myśl filozoficzna dotycząca zwłaszcza zagadnień etycznych, teologicznych, społecznych i politycznych z całą pewnością będzie odkrywana i studiowana przez przyszłe pokolenia, i to nie tylko uczonych w Polsce. Dlaczego? Ponieważ zawiera wyjątkowe walory poznania mądrościowego, łączącego poznanie naturalne (filozoficzne) z otwartością na dary i łaski Pana Boga, a walory te są uniwersalne i ponadczasowe (Mazur, Kiereś, Skrzyniarz, Płazińska, 2019).

Ojciec Woroniecki, jak nikt przed nim w kulturze polskiej, potrafił doskonale wskazywać jedność i integralność prawdy, dobra, piękna i świętości, tak w życiu indywidualnym, jak i rodzinnym oraz społecznym ${ }^{1}$. Czynił

Dr hab. PAwet Skrzydlewski, prof. PWSZ Chełm - Katedra Pedagogiki, Państwowa Wyższa Szkoła Zawodowa w Chełmie, adres do korespondencji: ul. Pocztowa 54, 22-100 Chełm; e-mail: pskrzydl@gmail.com; ORCID: https://orcid.org/0000-0003-2647-5939.

${ }^{1}$ Przykładem tego łączenia i ukazywania jedności tego, co prawdziwe, dobre, piękne i święte daje choćby jego praca Królewskie kapłaństwo, ukazująca bardzo mocno potrzebę odnowy życia narodowego, moralnego i duchowego Polski dzięki wytężonej pracy autentycznych kapłanów (Woroniecki, 2000, 1935, 2013). 
to wszystko z ogromną kulturą słowa i odpowiedzialnością (Woroniecki, 1961, s. 189-200). Dlatego cała jego etyka, antropologia i pedagogika przeniknięte są tą właśnie troską, aby uczynić człowieka jak najbardziej zdolnym do władztwa nad sobą oraz osobami powierzonymi jego pieczy. Jak to osiągnąć, jak to władztwo ludzkie się spełnia - oto centralne zagadnienia filozofii władzy o. Jacka Woronieckiego. Są one, jak pisał, centralnym zagadnieniem pedagogiki polskiej, która musi wychowywać człowieka do dobrego życia właśnie przez należyte sprawowanie władzy (Woroniecki, 1961, s. 59-92). Ale jak to czynić i dlaczego należy zagadnieniu temu poświęcić tak wiele uwagi?

\section{WORONIECKI O WSPÓŁCZESNYM ATAKU NA INSTYTUCJĘ WŁADZY}

Hasła „wyzwolenia” i „uwolnienia” człowieka, rodziny i całych społeczności od władzy usprawiedliwiane bywają dziś różnie: równością, wolnością czy też potrzebą partnerstwa i zniesienia wszelkich różnic. W sposób szczególny ideologia walki z ludzką, ale i także z Bożą władzą, została podjęta przez rozliczne ruchy odwołujące się do ideologii wolnomularskich (Jaroszyński, 2003, s. 771-772; Pelczar, 1914). Wszystkie one stanowią poważne zagrożenie dobra człowieka, tak w płaszczyźnie życia naturalnego, jak i nadprzyrodzonego. Mają one jeden wspólny mianownik, jakim jest negacja autentycznej ludzkiej władzy i wszelkiej innej, a w sposób szczególny władztwa samego Boga. Jak należy to rozumieć?

Afirmacja władzy, tworzenie prawdziwościowej jej teorii, teorii filozoficznej ma wielkie znaczenie nie tylko dla samej polityki i etyki, ale także dla pedagogiki i ogólnie całego ładu społecznego. Tych wszystkich spraw był świadom o. Woroniecki, najwybitniejszy polski etyk i moralista, baczny obserwator życia społecznego Zachodu, wielki pedagog i społecznik. Podkreślał on, że w czasach nowożytnych

Oderwanie się nauki o wychowaniu od swej nauki macierzystej, od etyki i teologii moralnej, okazało się dla obu fatalnem. Etykę i teologię moralną pozbawiało ono tego tak ważnego sprawdzianu, jakim dla każdej teorii jest praktyka i oddaliło je od życia i uczyniło mniej płodnemi; natomiast nauce o wychowaniu wyrwało z pod [sic!] nóg mocne podstawy teoretyczne i wystawiło ją na wpływy tej anarchii umysłowej, która ma swe początki w Reformacji (Woroniecki, 1924, s. 152).

Dziś z niezwykłego skarbca nauki Woronieckiego warto zwrócić uwagę na rozwijaną przez niego filozofię władzy, tak mocno realistyczną i aktualną, 
wielce potrzebną całej współczesnej kulturze polskiej, zwłaszcza tej rodzinnej, narodowej i państwowej (Woroniecki, 1992)². Ma ona kapitalne znaczenie dla całej praktyki wychowania człowieka również w instytucjach życia religijnego. Chodzi tu przede wszystkim o dostrzeżenie tego, czym jest w swej istocie władztwo ludzkie, jaki ma swój właściwy cel oraz jakimi środkami ono dysponuje, a także jakie formy działania władztwu temu towarzyszą. Jak się bowiem okazuje, Woroniecki wyjaśniał, że sprawowanie władzy nie jest czynnością prostą, ale złożoną, obejmującą rządzenie, rozkazywanie oraz karcenie, będące w swej istocie formą korektury, naprawy tego, co nie udało się należycie spełnić ${ }^{3}$. Woroniecki wyjaśniał, że sprawowanie władzy zakłada jej teorię, potrzebuje nie tylko uprawnienia do jej wykonywania, ale przede wszystkim dojrzałej osoby, udoskonalonej przez całą grupę cnót.

\footnotetext{
${ }^{2}$ Autor zauważa tam, że „W samej rzeczy ład i porządek społeczny jest w najwyższym stopniu od tego zależny, czy ci, co stoją na czele poszczególnych grup społecznych i całych społeczeństw, umieją nimi rządzić i bez wstrząsów prowadzić do właściwych im celów. Ale łatwe to nie jest, bo w tej dziedzinie trzeba oddziaływać na jednostki myślące, stanowiące o sobie i mogące zawsze okazać swój sprzeciw i rządom się nie poddać; trzeba umieć do nich podejść, zjednać sobie ich umysły i sprawić, aby same zechciały tego, co im się rozkazuje, aby przejęły do swej woli ten impuls, jaki od rozkazodawców dostają, a z nim i jego siłę" (Woroniecki, 1992, s. 9).

${ }^{3}$ Zasadniczym studium o. Woronieckiego o władzy ludzkiej jest jego niewielka praca Umiejętność rzadzenia i rozkazywania, której właściwe odczytanie wymaga uwzględnienia całego systemowego kontekstu nauki Woronieckiego. Jak wiadomo, kontekstem tym jest realistyczna filozofia Akwinaty oraz myśl teologiczna Kościoła katolickiego. Nie sposób tu całego tego kontekstu przedstawić, ale należy zwrócić uwagę przede wszystkim na antropologię Woronieckiego, ujmującą byt ludzki w kategoriach osoby ludzkiej (istoty rozumnej i wolnej, godnej i społecznej, ze swej natury powołanej do kierowania sobą i swym życiem ku ostatecznemu celowi, tj. Bogu, który jest nie tylko racją istnienia całego kosmosu, ale przede wszystkim jest spełnieniem człowieka. Władztwo ludzkie nad sobą i innymi ludźmi ma zatem tylko wtedy swój sens, gdy prowadzi do skutecznego i pełnego związania się człowieka z Bogiem, co dokonuje się dzięki nie tylko staraniom ludzkim, ale także dzięki Łasce Samego Boga. Władza ludzka zatem, choć sprawowana nad rzeczami, osobami niebędącymi własnością innych ludzi, jest władzą w kontekście Boga i ostatecznie dzięki Bogu. Nie oznacza to jakiejś teologizacji i sakralizacji ludzkiego władztwa, ale dostrzeżenie zasadniczego sensu wszelkiego sprawowania władzy. Współcześnie różne formy negacji władztwa ludzkiego, czy to nad sobą, czy nad swą rodziną, czy też jakąś inną zbiorowością, mogą dokonywać się głównie przez zanegowanie istnienia samego Pana Boga jako celu i przyczyny sprawczej całej rzeczywistości. Bez istnienia i afirmacji Absolutu niknie podstawa dla wyjaśnienia wszelkiego ładu, działania, wszelkiego władztwa i uprawnienia do tego, by je mieć, by je sprawować. Jeśli do tego jeszcze dołączy się fałszywa metafizyka, promująca irracjonalizm i woluntaryzm, władza ludzka albo całkowicie niknie, albo przeradza się w ślepą formę despotycznej ekspresji. Na temat władzy i posłuszeństwa zob. Szymańska (2011, 15-28).
} 


\section{WŁADZA LUDZKA}

Ojciec Woroniecki słusznie zauważa, że niski poziom wykształcenia ogólnego i filozoficznego w naszej ojczyźnie, rzutujący mocno na praktykę życia codziennego, sprawia, że samo wykonywanie władzy, czy to nad sobą, czy też nad powierzoną wspólnotą, bywa dla wielu sprawą bardzo trudną, jeśli nie niemożliwą ${ }^{4}$ I dlatego brak panowania nad sobą, brak należytego kierownictwa swym życiem (rodziną), nie staje się przyczyną nieszczęścia tylko tego, kto sam sztuki władzy nie posiada, ale przede wszystkim szkodzi innym, jest złem i wadą społeczną, rodzinną i polityczną. To zasadnicza teza Woronieckiego, która skłania go do namysłu nad władzą ludzką ${ }^{5}$. Czym jednak jest sama władza?

Jest ona nie tylko aktem ludzkim, ale także zasadniczo sprawnością osoby ludzkiej, sprawnością indywidualną, a jej funkcjonowanie ma społeczny i rodzinny wymiar. Sprawność ta najogólniej wyraża się poprzez rządzenie, rozkazywanie i karcenie, zaś jej istotą zawsze pozostaje właściwa troska i działanie o to, by to, co istnieje i działa, istniało i działało dla właściwego celu. Tak pojęta sztuka władzy ma swe osadzenie w cnocie roztropności, ale nie tylko w niej, ale i w całym ludzkim charakterze, całym wewnętrznym życiu osoby, jego sile i bogactwie (Rynio, Tomczyk, 2012, s. 13-47; Kalka, 2000; Kempys, 2005, 2006, 2007). Sprawność dobrego korzystania z władzy ogarnia zatem całego człowieka z wolą i intelektem. Osiąganie celu (dobra) ma się tu dokonywać nie tylko rozumnie, ale także dobrowolnie, bo cel musi być chciany, miłowany przez tego, kto działa dla niego ${ }^{6}$. Osoba, która przyczynia się aktywnie do tego stanu, która partycypuje w tymże istnieniu i działaniu uczestniczy we władzy, sprawuje władzę w jakimś zakresie.

\footnotetext{
${ }^{4}$ O pilnej potrzebie troski o zrozumienie władzy ludzkiej Woroniecki pisał: „Trzeba dać jasną i zwięzłą doktrynę sprawowania władzy, trzeba ją spopularyzować tak, iżby się stała przedmiotem ogólnego zainteresowania, a wtedy powoli zacznie ona przenikać do obyczajów i nadawać całemu społeczeństwu coraz większe zamiłowanie do ładu i karności” (Woroniecki, 1992, s. 12).

${ }^{5}$ Namysł ten prowadził on poniekąd przez cały okres swej twórczości pedagogicznej, przy różnych pracach, wykazując, że sprawowanie władzy jest dla każdego człowieka naturalną dla niego koniecznością, wynikającą ostatecznie z osobowego sposobu bytowania człowieka jako istoty obdarowanej rozumem i wolną wolą. Szukając zatem antropologicznych podstaw filozofii władzy u Woronieckiego - musimy w pierwszej kolejności wskazać na naturę człowieka i jego właściwy sposób działania, który wskazuje na zdolność człowieka do podejmowania decyzji, będących źródłem ludzkich uczynków.

${ }^{6}$ Wychowanie dotyczy człowieka i nie jest ani jego ideologizacją, ani manipulacją człowiekiem, ani też jakąś formą tresury, ale ostatecznie procesem doskonalenia przez cnoty (Woroniecki, 1947, s. 28-36, 165-174, 272-281).
} 
Władztwo zatem ludzkie jest zawsze związane z oddziaływaniem, z przyczynowaniem, $\mathrm{z}$ nadawaniem działaniu jakiegoś określonego kierunku, wreszcie $\mathrm{z}$ powodowaniem samego istnienia działania oraz $\mathrm{z}$ naprawianiem tego, co stoi w rozbieżności z doskonałością osiąganą dzięki celowemu działaniu. Władza rodzi zatem określone skutki, a jej ocena zależy od tego, jakie przynosi efekty. Zasadniczym efektem ma być doskonałość ludzka, wynikająca z osiągnięcia właściwego celu, tak partykularnego, jak i ostatecznego, ludzkiego życia.

Władzy i jej sprawowania uczy się, zdaniem Woronieckiego, każdy człowiek i to przez całe swe życie, a proces doskonalenia sprawowania władzy nigdy nie ma końca, bo realna działalność ludzka, dokonująca się w zmiennych i niekoniecznych okolicznościach indywidualnych i społecznych, zawsze może być lepsza, doskonalsza. Wychowanie zatem do władzy ma spełniać się przez całe życie i nikt nie jest $\mathrm{z}$ obowiązku doskonalenia swego władztwa zwolniony (Andrzejuk, 2000).

Rodzina jako pierwsze miejsce zaistnienia człowieka i jego rozwoju staje się, zdaniem Woronieckiego, także pierwszą szkołą władzy, a otrzymana przez człowieka w niej formacja umożliwia wszelki inny typ władzy, który będzie przez człowieka sprawowany.

\section{ZAGROŻENIA AUTENTYCZNEGO WŁADZTWA NAD SOBĄ I INNYMI - ATAK NA LUDZKI ROZUM I PRAWĄ WOLĘ: SENTYMENTALIZM, INDYWIDUALIZM, KOLEKTYWIZM}

Zdaniem Woronieckiego, sprawowanie władzy przez człowieka, podobnie jak i sama kultura moralna, na skutek naturalizmu i związanego z nim irracjonalizmu doznało i doznaje wielkiego zła. Współczesny sentymentalizm sprawił, że na władzę patrzy się dziś głównie przez pryzmat odczuć i przeżyć, nastrojów i emocji, tracąc z pola widzenia to, co dla władzy jest najważniejsze, tj. właściwe dla człowieka spełnianie dobra (Woroniecki, 1924, s. 143-160) Tym samym niknie z pola widzenia to, co w sprawowaniu władzy jest sprawą podstawową: rozumna i wolna forma postępowania ludzkiego spełniająca jakieś autentyczne dobro człowieka, dokonująca się dzięki rozumnemu kierownictwu, prawym rządom i właściwej korekturze (Woroniecki, 1935, s. 49-59, 128-139).

Woroniecki zauważył, że tak mocno rozpowszechniony w pedagogice i kulturze indywidualizm i egotyzm, nakazujący cenić człowiekowi przede 
wszystkim swoje tylko dobro, swoją swobodę działania, często w samym istnieniu władzy jednego człowieka nad drugim upatruje jakiejś formy niewolnictwa czy też gwałtu jednego nad drugim (pedagogika J.J. Roussea i jego duchowych następców).

Podległość w czymkolwiek jednej osoby drugiej jawi się tu jako forma poniżenia i niesprawiedliwości, a jeśli faktycznie się ona dokonuje, to istnieje na mocy jakiegoś utylitarnego kompromisu lub przemocy, szantażu, dominacji. Władza jest tu zatem jakby zjawiskiem niemoralnym, a nawet gdy jest sprawowana tylko nad sobą samym, to jawi się jako forma samoograniczenia, jako coś przykrego prowadzącego do utraty „czegoś”, zwłaszcza gdy władztwo nad sobą dokonuje się podług jakiejś zewnętrznej w stosunku do człowieka reguły (prawa).

Analizując zgubny dla władztwa ludzkiego zespół stanowisk, trzeba zdaniem Woronieckiego - zwrócić uwagę na kantyzm. Z jednej strony kantyzm jest pokłosiem indywidualizmu i agnostycyzmu i ostatecznie zmierza do zapewnienia całkowitej autonomii jednostce, uwalniając ją nie tylko od życia przyjemnego i pożytecznego, ale nieopartego na realizacji autentycznego dobra, gdyż miejsce dobra - celu i motywu działania zajmują tu projekcje indywiduum, zwane wartościami, które w żaden sposób nie istnieją w realnym, pozapodmiotowym świecie (Krąpiec, 2008, s. 704-708).

W kantowskiej etyce i pedagogice jednostka zatem jest „w służbie wartości”, które wcześniej sama wykreowała, by móc je zrealizować, a jej władza jest władztwem nad działaniem urzeczywistniającym wartości, które jednak „nie są” z realnego świata (Kiereś, 2008, s. 708-711). Cała zatem kantowska filozofia władzy jest skażona idealizmem i antyrealizmem, co powoduje, że wprowadzana w pedagogikę rujnuje samego człowieka i ład życia społecznego, oddając ludzkie życie w faktyczną despocję ,obowiązków bez prawdziwego dobra", ale i też bardzo często ludzkich wad (Chłodna-Błach, 2016, s. 164-169). Toteż Woroniecki zauważa, że indywidualizm antropologiczny chętnie zamieniłby wszelkie władztwo na spontaniczny akt ekspresji, wolnej, niczym nieuprzyczynowanej, w którym pierwszym najcenniejszym walorem jest autentyczność i zaangażowanie, bezinteresowność i autonomia.

Co to jednak znaczy, gdy przełożymy te koncepcje na codzienne, realne działanie w rodzinie, społeczności lokalnej, państwowej i narodowej? W praktyce oznacza to chaos, zwalczanie się nawzajem różnych działań, które nie mając jednego celu i zasady bytu, niszczą każdą wspólnotę i wszelki pojawiający się ład - bo różne i autonomiczne jednostki kierują się ku różnym i tylko własnym „wartościom”, które nie mają za wiele wspólnego 
z normalnym, codziennym życiem. W atmosferze chaosu i bezładu, rywalizacji i sprzeczności nie pojawi się żadne cenne dobro, takie choćby jak ludzkie wykształcenie, sam dobrobyt czy też przyjaźń, czy sama szczęśliwość człowieka dobrze wychowanego. Będzie natomiast wiele zła oraz ostatecznie nienawistnej rywalizacji, która kończy się czy to pognębieniem oponentów, czy to zniechęceniem i apatią, wynikającą z wyczerpania sił ducha i ciała.

\section{SKUTKI DEFORMACJI WŁADZY LUDZKIEJ}

Negatywny wpływ indywidualizmu na władztwo ludzkie, zdaniem Woronieckiego, szkodzi każdej wspólnocie ludzkiej od rodziny, aż po naród i państwo, często doprowadzając do przerodzenia się władztwa ludzkiego w jakąś formę despocji, gdzie o wszystkim rozstrzyga brutalna siła i interes. Podmiotem ich może być nie tylko jednostka, ale także zbiorowość, która miotana aprioryczną samowolą, niszczy wszystko, co cenne dla rozwoju człowieka, głosząc hasła progresu, tolerancji, demokracji i wolności, budowy nowego ładu na nowych „wartościach” (Woroniecki, 1921, s. 13-22, 58-73; Pańpuch, 2013, s. 41-68). Nie ma tu poszanowania dla praw, naturalnego porządku, nie ma świadomości ostatecznego celu istnienia tak człowieka, jak i całej wspólnoty, jest tylko pole eksperymentów i walki.

Woroniecki zauważa, że także kolektywizm przeczy potrzebie istnienia władzy ludzkiej jako takiej, w praktyce zamieniając ją w jakąś formę ograniczenia jednostki, jakiegoś jej podporządkowania koniecznym siłom, jakiejś ważniejszej od osoby całości. Jednostka nie może samodzielnie działać, bo jest tu jakby elementem całości, zależnym bytowo od kolektywu. On ma prawo do decyzji, do działania, do sprawstwa. Konkretny człowiek staje się tu środkiem i swoistym budulcem dla kolektywu, który uzbrojony w instrumenty państwowe ostatecznie używa jednostki dowolnie, nie licząc się ani z jej podmiotowością, ani suwerennością, ani godnością ludzką (Skrzydlewski, 2003, s. 223-254). Kolektywizm staje się ideologią totalną i - jako taka nieznoszącą istnienia ludzkiej, indywidualnej władzy, odpowiedzialności, inwencji, suwerenności (Rembierz, 2000, s. 207-233).

Woroniecki ostatecznie zauważył, że liczne błędy antropologiczne, społeczne i ideowe sprawiły, że wielu dziś wydaje się głosić niezwykle niebezpieczną koncepcje władzy, w której dochodzi do zatracenia ludzkiego dobra oraz samej instytucji władzy. Władza mylona bywa tu albo z jakąś formą nieograniczonej despocji, dominacji i używania czegoś lub kogoś, albo też 
jest przedstawiana $\mathrm{w}$ kategoriach postępowania dowolnego, niezwiązanego żadnym dobrem i prawdą, wręcz działania bezrozumnego, opartego na zachciankach, w których nie mają znaczenia naturalne relacje międzyludzkie, ani ustanowiony porządek przez Pana Boga (Woroniecki, 1992, s. 9-17). Wszystko to szkodzi autentycznej kulturze władzy ludzkiej nad sobą samym, władzy, jaką dzierżą rodzice nad dziećmi, przełożeni nad podwładnymi, naczelnicy państwa nad obywatelami.

$\mathrm{Na}$ marginesie, idąc za rozważaniami Woronieckiego, należy także dostrzec groźne i zgubne w swych następstwach próby usunięcia samej instytucji władzy jako takiej, jednego człowieka nad drugim, które dokonują się choćby przez oddziaływanie pewnych ideologii (tolerancji, partnerstwa, równości, egalitaryzmu, permisywizmu i inne). Ich sednem jest twierdzenie, że sam fakt wpływania i kierowania przez jednego człowieka drugim kłóci się z ludzką wolnością i podmiotowością, wreszcie z godnością, którą nosi w sobie człowiek. Podległość jednego człowieka jakiejś innej osobie miałaby być jej uprzedmiotowieniem i faktycznie zniewoleniem, wręcz zgodą na stan niewolnictwa.

Z tej racji likwidacja władzy jednego człowieka nad drugim, także wszelkich kar, jest nie tylko postrzegana jako droga do wyzwolenia, ale w ogólności jako warunek konieczny wszelkiego rozwoju człowieka, poszanowania jego praw i wolności. Rodzi się zatem swoista ideologia „bycia poza władzą" kogokolwiek, ideologia walki „o prawo wolności od władzy, od podległości”. Jej praktyczne ziszczenie ma przynieść spełnienie się człowieka. Ten anarchizm ma tu nie tylko polityczny (partyjny) wymiar, ale jak to często się zdarza, bywa elementem ideowym relacji międzyludzkich, rodzinnych, społecznych. Uwstecznia on ludzką kulturę, hamuje jej autentyczny rozwój i doskonalenie, by ostatecznie tak ukształtować człowieka, by ten stał się niewolnikiem swych zachcianek, słabości czy pewnych modnych trendów. A tak stać się musi, bo człowiek jest przecież dotknięty obecnością w nim zaczynu zła i wad, tzw. lex fomitis?

\footnotetext{
${ }^{7}$ Przypomnijmy, że lex fomitis to pewne zarzewie zła w człowieku, źródło i zaczyn złych ludzkich uczynków i wad wypływających ze zdefektowanej miłości siebie oraz z braku należnego w naturze ludzkiej ładu. Przejawem lex fomitis jest przede wszystkim pycha, pożądliwość oczu, czyli niewłaściwa i nadmierna miłość dóbr zewnętrznych oraz wypaczone pożądanie seksualne, nakazujące widzieć w drugim człowieku jedynie źródło i okazję swojej przyjemności seksualnej. Trzeba także pamiętać, że prawdziwie ludzka kultura, już choćby z racji natury ludzkiej, w której odnajdziemy różnorodne braki (defekty), wymaga do swego zaistnienia i funkcjonowania wsparcia i jej uszlachetnienia ze strony Absolutu, za pomocą środków nadprzyrodzonych (łaska Boża, sakramenty św.). Uszlachetnienie to i wsparcie nie znosi porządku natury, lecz go dopełnia.
} 
Poglądy anarchizmu przenikają do myśli pedagogicznej i faktycznie postulują pedagogikę bez władzy rodzicielskiej, wychowawczej, dyscyplinującej i korygującej nawet dzieci ${ }^{8}$. W atmosferze równości wszystkich we wszystkim, wolności od wszystkiego oraz fraternizacji każdego z każdym, niknie jakakolwiek racja do kierowania kimkolwiek prócz siebie samego, niknie podstawa dla służby i podległości. Ale to kierownictwo sobą ani nie ma osadzenia $\mathrm{w}$ jakimś sądzie rozumu, ani nie liczy się z dobrem wspólnym, dobrem innych, lecz jedynie kieruje się partykularnym interesem własnym, najczęściej zaś zachcianką. Nic dziwnego, że skutkuje to nie tylko konfliktami, bo interesy i same działania bywają rozbieżne, a nawet sprzeczne, ale także daje realny rozpad życia wspólnotowego, wreszcie unicestwienie samej wspólnoty.

Woroniecki argumentował, że bycie pod władzą nie tylko nie stoi w sprzeczności z ludzką godnością i suwerennością, ale faktycznie tę godność i suwerenność może umacniać, o ile samo sprawowanie władzy nad kimś ma na uwadze właściwy cel i posługuje się właściwymi środkami i sposobami. Bycie pod władzą może nawet być wprost czynnikiem doskonalącym, gdyż ten, kto jest uległy dobrej władzy, ma szansę partycypowania w owocach, jakie ta władza przynosi w postaci dobra. Człowiek ma wtedy szansę także uczyć się rządzenia i rozkazywania, różnych sposobów wprowadzania korektury, które potem posłużą w samodzielnym sprawowaniu władzy, gdy przyjdzie ku temu właściwy czas. Posłuszeństwo może stać się środkiem doskonalenia siebie nie tylko przez sprzyjanie pokorze, ale także przez wyrabianie w sobie panowania nad swymi wewnętrznymi przeżyciami (Szymańska, 2011, 15-28; Lisica, 2011, 45-61).

Doskonale problem ten zrozumiał św. Augustyn, który stoczył ideową walkę z dwoma stanowiskami: Tertuliana negującego istnienie kultury niewywodzącej się od Boga, co prowadziło do fideizmu i sakralizacji wszystkiego; oraz gnostyków, którzy głosili teorię samozbawienia się człowieka za sprawą naturalnych środków, a tym samym odrzucali łaskę Boga (Gmurowski, 1934; Św. Tomasz z Akwinu. STh I-II. q. 90, art. 6).

${ }^{8}$ Ostatnio w literaturze polskiej ukazała się praca A. Golus (2019). Praca sugeruje czytelnikowi, że przez wieki całe z racji władzy rodzicielskiej, stosowania kar cielesnych, lata dziecięce niemal wszystkich ludzi były czasem „strachu”, „terroru”, „krzywdy”, „,niewoli”, „gwałtu”, „przemocy”, słowem: czasem koszmarnego doświadczenia zła. Dopiero nowożytna i współczesna forma życia „wyzwoliła” i „wyzwala” z tego zła. „ZŁO” władzy rodziców nad dziećmi, jak i związana z nim zdolność do karcenia (zwłaszcza cielesnego) autorka wywodzi nie tylko z nauki moralnej pedagogów starożytnych, ale głównie z chrześcijaństwa i jego doktryny oraz związanej z chrześcijaństwem tradycji intelektualnej (św. Ambroży, Wincenty z Beauvais, św. Tomasz z Akwinu) (Golus, 2019, s. 47-50). Praca sugeruje, że „wyzwolenie” z „koszmaru dzieciństwa”, może się dokonać tylko tam, gdzie zostanie odrzucona ideologia przyczyniająca „ZŁO”. Co jest tym złem? Ogólnie można uznać, że cywilizacja Zachodu, czerpiąca swe siły z Objawienia, filozofii greckiej i rzymskiej. 


\section{PODSTAWY SPRAWOWANIA WŁADZY PRZEZ CZŁOWIEKA}

Woroniecki, podążając za naturalnym ludzkim doświadczeniem świata i człowieka, podobnie jak to czynił Akwinata czy wcześniej Arystoteles, wskazuje na naturalną konieczność istnienia władzy jako takiej i na fakt jej sprawowania przez człowieka nawet $\mathrm{w}$ sytuacji, gdy ten jest odseparowany od życia społecznego. Człowiek z racji tego, że jest bytem przygodnym, spotencjalizowanym i przyporządkowanym całym swym jestestwem do doskonalenia - musi działać, musi postępować, a dzięki swemu działaniu spełniać się i doskonalić.

To jednak, co różni go od innych istot żywych, to to, że sam ma moc kierowania swym działaniem, stanowienia o tym, jakie ono będzie i czy w ogóle ono zajdzie w tej konkretnej sytuacji. Człowiek bowiem nie jest jak zwierzę, jest osobą, a zatem podmiotem, sprawcą, kieruje się, a nie jest kierowany, działa, a nie ulega bezwiednie bodźcom. Może to czynić, gdyż ma naturę bytu osobowego, gdyż ma rozum i wolną wolę. Innymi słowy, podejmując rozważania dotyczące ludzkiej władzy oraz ludzkiego sprawstwa, zdaniem Woronieckiego, należy w pierwszej kolejności dostrzec, że dotyczy ono człowieka, a zatem istoty która działa na mocy swej rozumności i wolności, czyli zdolności do dokonywania decyzji (autodeterminacji siebie). Decyzyjność ludzka wraz z jej realizacją w postaci działań materializuje ludzką władzę, widoczną przede wszystkim w sprawstwie czynu, w sprawstwie ludzkiego działania (Woroniecki, 1929, s. 179-281).

Specyfika ludzkiej władzy oczywiście może być ukazywana na wiele sposobów, ale ostatecznie zawsze będzie wiązała się z dostrzeżeniem tego, że człowiek ma moc kierowania sobą, sprawiania czegoś i sprawstwo to jest istotnie różne od sprawstwa obecnego w świecie przyrody, gdzie działania zwierzęcia są pokierowane instynktem (naturą) i jako takie nie mają waloru rozumności ani wolności.

Co więcej, u zwierząt sens sprawstwa działań kryje się przede wszystkim $\mathrm{w}$ trwaniu i rozwoju nie tyle konkretnej jednostki, ale w istnieniu gatunku, pewnej zbiorowości jednostek (w trwaniu i doskonaleniu tego, co wydało jednostkę). $Z$ tej racji w świecie przyrody obserwujemy działania, które realnie mogą szkodzić jednostce, czy też nawet ją unicestwiać, ale w ostatecznym sensie służą one dobru gatunku, z którego jednostka wzięła swój byt i w którym się ostatecznie spełnia9.

\footnotetext{
${ }^{9}$ Dowodem na to są np. akty rozrodu (np. ryb, owadów), w których giną osobniki przekazujące życie. Obiektywnie - akt przekazywania życia nie prowadzi do dobra jednostki przekazującej
} 
Woroniecki, idąc za nauczaniem św. Tomasza z Akwinu i tradycji filozofii realistycznej, widzi w człowieku podmiot rozumny i zarazem wolny, który w sobie ma możność określenia swego działania. Możność ta zależy ze strony człowieka od jego władzy poznawczej (rozumu), ale także od władzy pożądawczej, jaką jest wola, gdyż to ona jest tym czynnikiem w człowieku, który sprawia działanie, wpływa też na jego formę, choćby przez kierowanie ludzkiego rozumu na określone tory postępowania, jakie podobają się woli. Tym samym władza ludzka jest władzą i rozumu, i woli, jest przez działanie tychże władz w człowieku.

Podkreślenie związku władzy ludzkiej z rozumem i zarazem wolą jest bardzo ważne, gdyż z racji błędnych tendencji do intelektualizm moralnego $\mathrm{w}$ wielu systemach pedagogiki dochodzi do błędnego zredukowania woli człowieka do pewnego ciągu przeżyć o charakterze poznawczym, w którym sama wola i chcenie zostanie porzucone na rzecz pewnych procesów kojarzenia i procesów myślenia, gdzie ostatecznie ludzki czyn jest efektem „pewnej wewnętrznej logiki” operacji samego rozumu.

Woroniecki podkreślał, że takie redukcjonistyczne ujęcie woli jest jej faktycznym zlekceważeniem i niezrozumieniem jej istoty i funkcji w życiu moralnym. Przynosi to fatalne skutki dla całej kultury moralnej i pedagogiki, która $\mathrm{z}$ wychowania faktycznie czyni proces wpływania na ludzki intelekt (aparat poznawczy) z pominięciem formacji woli, której się po prostu nie dostrzega i pozostawia bez doskonalenia. Pedagogika staje się tu tylko przestrzenią edukowania, informowania, przekazywania wiedzy, przy założeniu że ma ona moc sprawstwa niejako automatyczną i samorzutną. Tak przecież nie jest $\mathrm{t}^{10}$.

życie, ale raczej do jej zła, jakim jest jej własne unicestwienie. Ale jednak natura (instynkt) „używa” jednostki i sama jednostka jest we władzy tejże natury, a raczej pod władzą instynktu, ulegając jej zazwyczaj całkowicie. Zwierzę z racji tego, że jest zwierzęciem, nie kieruje sobą, ale jest kierowane, nie ma władzy nad sobą, ale jest pod władzą czegoś, co sprawia jego działanie. $\mathrm{Z}$ tej racji w tradycji filozofii realistycznej zwykło się podkreślać różnicę, jaka istnieje między działającym człowiekiem a zwierzęciem będącym podmiotem i przedmiotem działania, kierowanego przez instynkt (Św. Tomasz z Akiwinu. STh I. q. 83. art. 1. resp.).

${ }^{10}$ Woroniecki wyjaśniał, że „Tu ma swe źródło to głębokie spaczenie nowożytnej myśli moralnej wszystkich kierunków i obozów, spaczenie, które nazywamy intelektualizmem moralnym. Polega ono na zapoznaniu roli, jaką odgrywa w naszem życiu moralnym ta duchowa władza pożądania, którą nazywamy wolą, w szczególności dla zapoznawania jej wpływu na działalność rozumu w dziedzinie praktycznej i na pomijaniu tego udziału, jaki ona bierze $\mathrm{w}$ formowaniu sądów praktycznych, kierujących naszem postępowaniem moralnym. Intelektualizm moralny zaciera niemal wszelkie różnice między teoretyczną i praktyczną czynnością rozumu, a w działalności moralnej nie widzi nic innego jak logiczne następstwo - konieczne lub wolne - pewnego teo- 
Tymczasem ludzka wiedza obecna w rozumie nie sprawia jeszcze samego ludzkiego działania, a urzeczywistnia go dopiero ludzka wola, z której płynie miłość lub odraza ku temu, co poznane i co stanowi przedmiot i motyw działania. Władztwo ludzkie jest zatem władztwem woli i rozumu, a nie tylko woli i nie tylko rozumu. Rzecz oczywista, że ludzki rozum jest tylko wtedy władny kierować, gdy jest udoskonalony wiedzą (prawdą), gdy jest rozumem prawym (Maryniarczyk, 2007, s. 672-674). Podobnie także i wola, ma ona swą moc władztwa, gdy podąża za dobrem i lgnie ku dobru autentycznemu, właściwemu, a nie ku dobrom pozornym. Wola, by mogła władać, musi także być wolą prawą (Krąpiec, 1995-1996, s. 37-48).

\section{ZAKOŃCZENIE}

Woroniecki ma świadomość tego, że sprawowanie władzy czy to nad sobą, czy też nad innymi osobami nigdy nie było i nie będzie łatwe. Warto zauważyć, że samo rozumienie władzy jest u niego mocno osadzone w koncepcji człowieka. Jako przedstawiciel realizmu poznawczego i wierny uczeń św. Tomasza widzi w człowieku przede wszystkim rozumny podmiot, który działa na mocy swego rozumu i wolnej woli. Władztwo ludzkie jest władztwem wynikającym z mocy decydowania, sama zaś ludzka decyzja jest skutkiem poznania i miłowania jakiegoś dobra. $Z$ tej racji dobre sprawowanie władzy jest możliwe tylko tam, gdzie dokonują się właściwe decyzje, gdzie działa rozum pokierowany prawdą i wola pożądająca autentycznego i właściwego dobra.

Trzeba tu także dostrzec, że chodzi o władzę człowieka, czyli istoty godnej. $Z$ tej racji każdy akt władztwa, czy to nad sobą, czy nad innym człowiekiem lub grupą ludzi, będzie zawsze w kontekście wielkiego dobra, jakim jest właśnie ludzka godność. Woroniecki podkreślał, że realizm sprawowania władzy czy to nad sobą, czy nad innymi musi także uwzględniać i to, że zawsze będą istnieć pewne czynniki oporu wobec aktu władzy, czy to wynikające z obecności wad (pychy, głupoty, nieumiarkowania, złych nawyków), czy też jakichś innych elementów.

Ten także, kto dzierży władzę, musi liczyć się z tym, że podległe mu osoby zawsze będą dysponowały czymś, co może zostać użyte przeciwko władzy, a nawet co może zniszczyć jej samo istnienie. Władztwo ludzkie nie

retycznego rozumowania. Na chcenie nie ma tu miejsca, a gdy się o niem mówi, to widzi się w niem tylko pewien przejaw myślenia" (Woroniecki, 1924, s. 154). 
jest bowiem jak władztwo Boga (nieskończone i wszechmocne), ale jest właśnie władztwem ludzkim, na wiele sposobów uprzyczynowanym czynnikami zewnętrznymi, istotnie determinującymi jego sprawowanie i wykonanie. Dlatego, zdaniem Woronieckiego, analizując sprawowanie władzy przez człowieka, trzeba uwzględniać bardzo wiele elementów i okoliczności. Ważna jest ogólna atmosfera ludzkiego życia, w której panuje ład oraz jest przewidywalność skutków danych działań, a także powszechna zgoda co do ich zasad oraz form ziszczania.

Woroniecki w wielu miejscach podkreślał, że brak uległości wobec władzy ma swe przyczyny nie tylko ze strony podwładnych, ale także ze strony sprawujących rządy, którzy często źle rządzą. Pisał, że trudno wymagać od osoby, by była dobrowolnym uczestnikiem złych działan, zwłaszcza wtedy, gdy przynoszą one zło poważne i trwałe, zaś sama podległość wiąże się z byciem zarządzanym przez ludzi kiepskich, gorszych od podwładnych ${ }^{11}$. Zdaniem Woronieckiego, opór, jaki się pojawia wobec złej władzy, może być czymś naturalnym i dobrym, świadczącym o dojrzałości ludzi i o ich przywiązaniu do dobra wspólnego i nie może jako taki być brany jako argument przeciwko istnieniu samej instytucji władzy, która z racji pochodności całej rzeczywistości od Boga i przyporządkowaniu jej do Boga, ma swe źródło w Bogu, wyjaśniał Woroniecki.

\footnotetext{
${ }^{11}$ Warto w tym kontekście przywołać słowa Jacka Woronieckiego: „Nieraz się słyszy, że najlepszą szkołą rządzenia i rozkazywania jest posłuszeństwo. I tak jest niewątpliwie, ale pod jednym warunkiem, aby to było posłuszeństwo rozumianym (rozumnym) rozkazom. Posłuszeństwo względem przełożonych, nie umiejących rozumnie rozkazywać, nikogo rozumnego rozkazywania nie nauczy, ale raczej zaprawi do tych samych błędów i niedomagań w sztuce rządzenia, jakich przykłady miało się wciąż przed oczami. Trzeba szczególnych zdolności i mocy ducha, aby od nieudolnych rozkazodawców nie przejąć ich nieudolności, ale przeciwnie, siłą przeciwieństwa, widząc fatalne skutki, jakie złe rządy za sobą pociągają, wysnuć prawdziwe ich zasady. Znajdujemy się pod tym względem w Polsce w sytuacji wyjątkowo trudnej. Z jednej bowiem strony jako podłoże wspólne naszej psychiki przeważa u nas temperament sangwiniczny, który nie zawiera, w przeciwieństwie do cholerycznego, tego zmysłu władczego, jaki Francuzi nazywają le fluid imperatif, tj. chęci i zdolności oddziaływania na wolę innych. Z drugiej i dzieje nasze tak się układały, żeśmy nie wytworzyli sobie jakiejś trwałej tradycji pod tym względem. Nie przeszliśmy ani w średnich wiekach mocnej szkoły feudalizmu, ani w nowożytnych czasach też pod wieloma względami cennej szkoły oświeconego absolutyzmu. Przeciwnie, już okres elekcyjny naszych dziejów wytworzył w naszych obyczajach społecznych pewną tradycję niekarności, która w XIX w. z konieczności została jeszcze umocniona przez opór okazywany zaborcom. Dodajmy do tego i atmosferę umysłową ostatniego wieku przesiąkniętą indywidualizmem i tak skłonną gloryfikować bunt jednostki przeciw społeczeństwu, a będziemy musieli dojść do przekonania, że rozpoczęliśmy nowy okres naszego bytu niepodległego silnie obciążeni w dziedzinie karności społecznej” (Woroniecki, 1992, s. 10-11).
} 
Ów godnościowy, moralny wymiar władzy uwyraźnia się przed nami szczególnie mocno, gdy porównamy władanie i kierowanie np. nad rzeczą lub istotą żywą z kierowaniem i rządzeniem ludźmi. Co można uczynić np. z krzesłem, tego nie można uczynić np. z psem; co można uczynić z dzieckiem czy osobą dorastającą, tego nie można $z$ osobą dojrzałą i w pełni wolną $^{12}$. Władza zatem ma niejedno imię, a jej dobre sprawowanie zakłada nie tylko umiejętności podmiotowe, ale uwzględnienie licznych czynników zewnętrznych, nie mówiąc już o intencjach i środkach, a także samym uprawnieniu do jej sprawowania.

To co Woroniecki szczególnie mocno podkreślał, to konieczność bycia nie tylko dobrym człowiekiem do sprawowania władzy, ale bycia kimś lepszym od tych, nad którymi władzę się sprawuje. Lepszość ta, co oczywiste, nie dotyczy przyrodzonej godności, bo w tej wszyscy ludzie są sobie równi, ale godności nabytej, będącej efektem zasług i uczynionego dobra. Rodzice zatem z racji bycia przyczyną istnienia dziecka, jego wykarmienia i wychowania, ochrony i wielkiego trudu, jaki wnieśli - mają prawo do władzy nad dzieckiem i mają samą władzę nad nim. Przez analogię sprawa ma się podobnie do wspólnoty państwowej, społecznej, religijnej.

Samo sprawowanie władzy, co nieustannie podkreśla Woroniecki, jest nie tylko trudne, ale przede wszystkim jest formą służby drugiemu człowiekowi

${ }^{12} \mathrm{~W}$ każdym rodzaju władzy jest jakiś rodzaj sprawstwa i możności dysponowania czymś, przemieniania czegoś w jakimś aspekcie i powodowania jakiegoś działania tego, co jest we władzy. Trzeba jednak mieć na uwadze kto, jak, dlaczego, jakimi środkami i sposobami sprawuje władzę. O ile człowiekowi wolno (może on) np. kopnąć swoje krzesło w swoim gabinecie, wyrzucić je na śmietnik (np. w chwili zdenerwowania), o tyle nie wolno tego zrobić z psem, tym bardziej z człowiekiem. Dlaczego? Bo działanie to nie konweniuje do dobra, do sposobu ludzkiego działania, bo nie doskonali ono człowieka, a przynosi mu ujmę. Rodzic na mocy bycia przyczyną istnienia dziecka, na mocy dobra, jakie mu nieustannie wyświadcza, ma uprawnienie do sprawowania władzy nad dzieckiem, ale uprawnienie to nigdy nie było i nie będzie absolutne, dające możność do poniżającego traktowania dziecka czy też okaleczania go. Uprawnienie to pozwala karcić dziecko, kierując się jego dobrem i ogólnymi zasadami panującymi w społeczności. Zasady te przez wiele lat pozwalały na stosowanie wobec dzieci kar cielesnych (nie zaś przemocy i bicia!!!). Współczesny bunt wobec stosowania kar cielesnych jest efektem wybujałego intelektualizmu moralnego, jaki wdziera się ze wszystkimi złymi skutkami do kultury i pedagogiki. Przynosi on bardzo wiele zła i rodzi ostatecznie ogromną przemoc fizyczną w wielu obszarach ludzkiej kultury, bo bezkarność dzieci i młodzieży przeradza się często w zwykłą przestępczość, deprawację i dewastację wszystkiego. Uwzględniając swoistość cywilizacji łacińskiej, warto podkreślić, że zakaz prawny stosowania kar cielesnych, z jakim dziś mamy do czynienia w wielu krajach - jest prostą drogą do przejmowania i zawłaszczania przez państwo (aparat urzędniczy) dzieci od rodziców; służy zamianie roli i funkcji rodzica na rzecz opiekuna i wychowawcy norm władzy publicznej, głównego źródła finansowania działań dziecka, za które ono samo nie ponosi odpowiedzialności. Jest to stan poważnej niesprawiedliwości, który rodzi niepokój nie tylko w rodzinach, ale w całej przestrzeni życia publicznego. 
poprzez rządzenie nim, wydawanie mu poleceń lub zakazów, a także poprzez karcenie - czyli korekturę, naprawę tego, co niedoskonałe. Duszą autentycznej władzy musi zatem być miłość i zrodzona z niej życzliwość, władza autentyczna jest zawsze przeniknięta cnotą pietyzmu, jest postacią służby dla dobra. Charakter tejże służby jest przede wszystkim moralny i nakierowany na autentyczną doskonałość człowieka, tak sprawującego władzę, jak i będącego pod władzą. Nie ma niczego z niewolniczego despotyzmu, ale jest formą oddziaływania roztropnego i godziwego, który uwzględnia samodzielność i prawa tego, kto się pod władzą znajduje.

Co ważne - cała forma sprawowania władzy, zdaniem Woronieckiego, czy to w przypadku rodziny, czy przedsiębiorstwa, państwa, czy jakiejkolwiek innej wspólnoty, dokonuje się w kontekście i dla dobra wspólnego. Ukazuje ona władzę człowieka nad człowiekiem w kategoriach roztropnej służby dobru wspólnemu, działalności moralnej, w której chodzi nie tyle o jakąś formę zdominowania i sprawnego zawłaszczenia drugiego człowieka, ale o usprawnienie go do czegoś, co jest konieczne i naturalne, dobre moralnie.

Dla Woronieckiego sprawowanie władzy nad sobą, innymi osobami, okazuje się być obowiązkiem ludzkim, także swoistą sztuką i umiejętnością potrzebną do pełni osobowego rozwoju człowieka, ale także do samego istnienia życia tak indywidualnego, jak i rodzinnego oraz społecznego.

\section{BIBLIOGRAFIA}

\section{PRACE O. JACKA WORONIECKIEGO}

WoronieCKI, J. (1921). Wychowanie społeczne i praca społeczna. Prąd, 9(1-2), 13-22.

Woroniecki, J. (1924). Paedagogia perennis: Św. Tomasz a pedagogika nowożytna. Przegląd Teologiczny, 2(3), 143-160.

WoronieCKI, J. (1929). Etyka. W: Zarys filozofii: praca zbiorowa (s. 179-281). Lublin: Towarzystwo Wiedzy Chrześcijańskiej.

Woroniecki, J. (1935). Chrześcijańskie wychowanie charakteru wysnute z dogmatu. Szkoła Chrystusowa, 6(10)2, 49-59; 6(10)3, 128-139.

WoronieCKi, J. (1935). U podstaw kultury katolickiej. Poznań: Naczelny Instytut Akcji Katolickiej.

Woroniecki, J. (1947). Program integralnej pedagogiki katolickiej. Ateneum Kapłańskie, 47, 28-36, 165-174, 272-281.

WORONIECKI, J. (1961). Długomyślność jako właściwa cnota wychowawcy. W: Wychowanie człowieka. Pisma wybrane, wyboru dokonał K. Szymański i opracował J. Kołątaj (s. 189-200). Kraków: Znak.

Woroniecki, J. (1961). Rozwój osobistości człowieka. Dynamiczny aspekt personalizmu. W: J. WORONIECKI, Wychowanie człowieka. Pisma wybrane (s. 59-92). Kraków: Znak.

WorONIECKI, J. (1992). Umiejętność rządzenia i rozkazywania. Wrocław: Tum. 
Woroniecki, J. (2000). Królewskie kapłaństwo. Studium o powołaniu i wychowaniu kapłana katolickiego. Warszawa: Oficyna Wydawnicza Viator.

WoroniecKi, J. (2013). Katolicka etyka wychowawcza, t. 1-3. Lublin: Wydawnictwo Fundacja Servire Veritati Instytut Edukacji Narodowej-Wydawnictwo KUL.

\section{OPRACOWANIA I LITERATURA POMOCNICZA}

AndrzejuK, A. (2000). Prawda o dobru. Problem filozoficznych podstaw etyki tomistycznej. Warszawa: Wydawnictwo UKSW.

ChŁodna-BŁach, I. (2016). Od paidéi do kultury wysokiej. Filozoficzno-antropologiczne podstawy sporu o kulturę. Lublin: Polskie Towarzystwo Tomasza z Akwinu.

GMurowski, A. (1934). Doskonatość chrześcijańska w myśl zasad św. Tomasza z Akwinu. Gniezno: Księgarnia św. Wojciecha.

Golus, A. (2019). Dzieciństwo w cieniu rózgi. Historia i oblicza przemocy wobec dzieci. Gliwice: Wydawnictwo Helios.

Jaroszyński, P. (2003). Iluminizm. W: A. MARyniarCZYK (red. nacz.), Powszechna encyklopedia filozofii, t. 4 (s. 771-772). Lublin: Polskie Towarzystwo Tomasza z Akwinu.

StĘPIEŃ, K. (red.), (2003). Błąd antropologiczny. Zadania wspótczesnej metafizyki (s. 223-254). Lublin: Polskie Towarzystwo Tomasza z Akwinu.

KALKA, K. (2000). Filozoficzna antropologia tomistyczna okresu międzywojennego w Polsce jako podstawa kształtowania charakteru. Bydgoszcz: Wydawnictwo Uczelniane Akademii Bydgoskiej.

Kempys, M.J. (2005). Rola cnót moralnych $w$ dążeniu ku petni czlowieczeństwa $w$ świetle pism o. Jacka Woronieckiego. Kraków: Wydawnictwo Naukowe PAT.

KemPYs, M.J. (2006). Zagadnienie rozwoju osoby ludzkiej w ujęciu o. Jacka Woronieckiego. Polonia Sacra, 10(18), 229-242.

Kemys, M.J. (2007). Charakterystyka gniewu na podstawie pism o. Jacka Woronieckiego. Polonia Sacra, 11(20), 241-256.

Kiereś, H. (2008). Wartości teoria. W: A. MARYNiARCZyK (red. nacz.), Powszechna encyklopedia filozofii, t. 9 (s. 708-711). Lublin: Polskie Towarzystwo Tomasza z Akwinu.

KrĄPIEC, M.A. (1995-1996). Afirmacja Boga w ludzkiej moralności. Roczniki Filozoficzne, 53-54 (2), 37-48.

KrąPiec, M.A. (2008). Wartość. W: A. Maryniarczyk (red. nacz.), Powszechna encyklopedia filozofii, t. 9 (s. 704-708). Lublin: Polskie Towarzystwo Tomasza z Akwinu.

LisicA, J. (2011). Cnota cierpliwości w kontekście aretologii św. Tomasza z Akwinu. Studia Gdańskie, 24, 45-61.

MaryniarczyK, A. (2007). Recta ratio. W: A. MARYNiARCZyK (red. nacz.), Powszechna encyklopedia filozofii, t. 8 (s. 672-674). Lublin: Polskie Towarzystwo Tomasza z Akwinu.

Mazur, P.S., Kiereś, B., Skrzyniarz, R., PŁazińska A. (2019). Jacek Woroniecki. Kraków: Wydawnictwo Naukowe Akademii Ignatianum.

PAŃPUCH, Z. (2013). Doniosłość antropologiczna pedagogiki Jacka Woronieckiego. W: Katolicka etyka wychowawcza (s. 41-68). Lublin: Fundacja Servire Veritati Instytut Edukacji Narodowej.

PelCZAR, J.S. (1914). Masonerya. Jej istota, zasady, dążności, początki, rozwój, organizacja, ceremoniat i działanie. Wedtug pewnych przeważnie masońskich źródet. Kraków: Nakładem autora.

REMBIERz, M. (2000). „Sensus catholicus”. Uniwersalizm, obiektywizm, realizm. Myśl fillozoficzno-teologiczna i działalność pedagogiczno-duszpasterska Jacka Woronieckiego OP w rozpra- 
wach i wspomnieniach Stefana Swieżawskiego. W: J. GAŁKowski, M.L. Niedziela (red.), Człowiek - moralność - wychowanie. Życie i myśl Jacka Woronieckiego OP (s. 20-233). Lublin: Towarzystwo Naukowe KUL.

RYNIO, A., TOMCZYK, M. (2012). Sprawności moralne jako elementy konstytutywne w formowaniu moralnego charakteru w twórczości o. Jacka Woronieckiego. W: I. JAZUKIEWICZ, E. KWIATKOWSKA (red.), Sprawności moralne w wychowaniu - wyzwania i rzeczywistość (s. 13-47). Szczecin: Przedsiębiorstwo Produkcyjno-Handlowe Zapol Dmochowski, Sobczyk.

SKRZYDLEWSKI, P. (2003). Błąd antropologiczny w teoriach społecznych. W: A. MARYNIARCZYK, B.E. SzYMAŃSKA (2011). Aktualność nauczania św. Bazylego Wielkiego na temat posługi przełożonego. Studia gdańskie, 24, 15-28.

WistubA, G. (2003). Ojca Jacka Woronieckiego paedagogia perennis. Cywilizacja, 7, 235-246.

\section{FILOZOFIA WŁADZY W UJĘCIU OJCA JACKA WORONIECKIEGO}

\section{STRESZCZENIE}

Ojciec Jacek Woroniecki na kartach licznych swych prac zaprezentował bardzo ważną koncepcje władzy ludzkiej. W koncepcji tej wykazał, że sprawowanie władzy jest działaniem moralnym człowieka, mającym swe uzasadnienie i wyjaśnienie w naturze osoby ludzkiej. Władza ludzka jest, zdaniem Woronieckiego, efektem posiadania przez człowieka cnoty roztropności. Woroniecki wykazywał, że pierwszą szkołą władzy jest zawsze rodzina, miejsce zaistnienia i wychowania człowieka. Dobre uformowanie w człowieku władztwa wymaga przede wszystkim znajomości prawdy o człowieku oraz jego przeznaczeniu, a także formach i sposobach życia. Woroniecki przestrzegał przed licznymi nowożytnymi ideologiami deformującymi ludzką władzę. Całe swe rozważania nad władzą oparł na myśli św. Tomasza z Akwinu oraz na filozofii realistycznej związanej z Akwinatą oraz Arystotelesem.

Słowa kluczowe: Woroniecki Jacek; filozofia władzy; etyka; antropologia.

\section{PHILOSOPHY OF HUMAN POWER \\ IN THE PERSPECTIVE OF FATHER JACEK WORONIECKI}

SUMMARY

Father Jacek Woroniecki presented numerous important works of human power in the pages of his many works. In this concept he showed that the exercise of power is a moral action of man, having its justification and explanation in the nature of the human person. According to Woroniecki, human power is the result of man's virtue of prudence. Wroniecki showed that the first school of power is always a family, a place of existence and education of man. A good formation of power in man requires knowing the truth about man and his destiny as well as forms and ways of life. Woroniecki warned against numerous modern ideologies deforming human power. He based all his reflections on power on the thoughts of Saint. Thomas Aquinas and on realistic philosophy associated with Aquinas and Aristotle.

Key words: Woroniecki Jacek; philosophy of power; ethics; anthropology. 